\title{
ECOPHYSIOLOGICAL AND METABOLIC ADAPTATIONS TO SULPHIDE EXPOSURE OF THE OYSTER CRASSOSTREA GIGAS
}

\author{
GILLES LE MOULLAC, ${ }^{1 *}$ MARIE CHEIZE, ${ }^{2}$ OLIVIER GASTINEAU, ${ }^{2}$ JEAN-YVES DANIEL, ${ }^{2}$ \\ JEAN RENÉ LE COZ, ${ }^{2}$ ARNAUD HUVET, ${ }^{2}$ JEANNE MOAL, ${ }^{2}$ STÉPHANE POUVREAU, ${ }^{1}$ \\ ALAIN VAN WORMHOUDT ${ }^{3}$ AND JEAN FRANÇOIS SAMAIN ${ }^{2}$ \\ ${ }^{1}$ UMR 100 Physiologie et Ecophysiologie des Mollusques Marins, IFREMER, Site Expérimental \\ d'Argenton, Presqu'île du Vivier, 29840 Argenton en Landunvez, France; ${ }^{2}$ UMR 100 Physiologie et \\ Ecophysiologie des Mollusques Marins, IFREMER, Centre de Brest, BP 70, 29280 Plouzané, France; \\ ${ }^{3}$ UMR 5178 , Biologie des Organismes et des Écosystèmes Marins, Station de Biologie Marine du Muséum \\ National d'Histoire Naturelle, BP 225, 29900 Concarneau, France
}

\begin{abstract}
The purpose of this study is to examine the response of the oyster Crassostrea gigas to sulphide at different biological scales. A first experiment was designed to measure for $20 \mathrm{~h}$ the clearance (CR) and oxygen consumption (OC) rates of oysters exposed at different concentrations of sulphide $(0,3,6,12,20$, and $40 \mu \mathrm{M})$. The second experiment was carried out to evaluate the metabolic adaptations to chronic sulphide exposure for 10 days by measuring PK and PEPCK enzyme activities, succinate and alanine content, the adenylate energy charge (AEC), and the activity of the electron transport system (ETS) in whole oysters at above $20 \mu \mathrm{M}$. PK and PEPCK mRNAs and enzyme activities have been measured in adductor muscle. When exposed to sulphide above $20 \mu \mathrm{M}, \mathrm{CR}$ stopped, whereas oyster maintained their average OC rate between 1 and $2 \mathrm{mg} \mathrm{O}_{2} \mathrm{~h}^{-1} \mathrm{~g}^{-1} \mathrm{dw}$. In the second experiment, sulphide exposure of oysters resulted in higher mortality, reduced the glycolytic flux by inhibiting the PK activity and decreased the ETS activity leading to a lower AEC. At day 10, a kind of recovery took place: the ETS activity and AEC of oysters exposed to sulphide increased to the level of the control oysters. In the adductor muscle, sulphide did not affect the transcriptional level of PK; PK was only regulated at enzyme level. Conversely, PEPCK was regulated only at transcriptional level. Nevertheless, muscle exhibited a wholly anaerobic metabolism by the significant increase of alanine and succinate contents followed by the significantly decrease of the ATP content during the 10 days of the experiment. This experiment showed that sulphide involved partially the whole oyster and wholly the adductor muscle in an anaerobic pathway of energy production; but oxygen was needed for the detoxification of the organism.
\end{abstract}

KEY WORDS: Oyster, sulphide, Crassostrea gigas, clearance rate, oxygen consumption, pyruvate kinase, phosphoenolpyruvate carboxykinase, alanine, succcinate, electron transport system, AEC, ATP

\section{INTRODUCTION}

Serious mortality outbreaks have been reported in Crassostrea gigas populations on the French coasts over the past $15 \mathrm{y}$ (Goulletquer et al. 1998, Soletchnik et al. 1999). The syndrome is known as summer mortality and is generally associated with temperatures above $19^{\circ} \mathrm{C}$ and coincides with the period of gonad maturation. Some authors suggest that mortalities occurring in the Pacific oyster are the result of multiple factors, including elevated temperatures, physiological stress associated with gonadal maturation, genetic, aquaculture practices, pathogens, and pollutants (Samain et al. 2007, Dégremont et al. 2005). Another stress resulting from the close proximity to the bottom sediment has also been recorded and has been shown to affect growth and survival of oysters (Soletchnik et al. 1999, 2006). Sediment is often hypoxic, but the highest oxygen demand can be in the water close to the bottom (Diaz \& Rosenberg, 1995). Hypoxia favors the production of toxic substances such as sulphides and ammonia in the sediment, and their appearance is synchronous with the mortality episodes. The seasonal character of ammonium and sulphide as well as the contributions of herbicides, domestic and agricultural manuring, represent a potential source of stress in the oyster zone and coincide with the period of mortality of oysters. Separately or in combination, these factors become noxious for oysters. This kind of problem can be illustrated in many areas.

\footnotetext{
*Corresponding author. E-mail: Gilles.Le.Moullac@ifremer.fr
}

For example, anoxic crises occur in summer in the lagoon of Thau (Herault, France) close to the Mediterranean Sea. The core of the anoxia develops with the production of hydrogen sulphide. The sulphide concentrations are high in anoxic water reaching $300 \mu \mathrm{mol} \mathrm{L}^{-1}$ at the bottom (Chapelle et al. 2001). In the Chesapeake Bay on the east coast of the United States, sulphide values of surface sediment reach $100 \mu \mathrm{mol} \mathrm{L}^{-1}$ to 2,000 $\mu \mathrm{mol} \mathrm{L}{ }^{-1}$ and $43 \mu \mathrm{mol} \mathrm{L}{ }^{-1}$ in the bay water (Roden \& Tuttle 1992). Similarly, in deep water off Rhode Island, the sulphide levels may reach $800 \mu \mathrm{mol} \mathrm{L}{ }^{-1}$ (Kennett \& Hargraves 1985).

From a physiological point of view, sulphide exposure increases the susceptibility of organisms to other environmental stressors. The reduction of feeding activity and oxygen consumption is a frequently observed response to hypoxia and sulphide exposure in invertebrates (Sobral \& Widdows 1997, Encomio 1998, Hicks \& McMahon 2002). For some species, the metabolic depression caused by the switch from aerobic to anaerobic energy production, which has a lower energy yield is caused by hypoxia and anoxia (Shick et al. 1986, De Zwaan et al. 1991) or to sulphide exposure (Encomio 1998, Laudien et al. 2002). The metabolic switch is controlled by several means such as the phosphorylation of PK (Simpfendörfer et al. 1997, Greenway \& Storey 1999), and the level of alanine leads to a reduction in its activity. When this occurs, PEP becomes mainly a substrate for PEPCK leading to the formation of succinate. At the mitochondrial level, the synthesis and degradation of the macroenzymes of the electron transport system (ETS) is a 
function of the respiratory requirements of marine organisms (Owens \& King 1975).

The purpose of this study was to examine the adaptation levels of the oyster $C$. gigas to sulphide. Two experiments were carried out. The first was to measure for $20 \mathrm{~h}$ the clearance and oxygen consumption rates of oysters subjected to different concentrations of sulphide. The second was done to evaluate the metabolic adaptation to chronic sulphide intoxication for 10 days by measuring PK and PEPCK enzyme activities as well as alanine, succinate and lactate content in whole oysters. The adenylate energy charge (AEC) was measured, and the activity of the respiratory chain was evaluated by measuring the electron transport system (ETS) activity (Madon et al. 1998, Fanslow et al. 2001). Lastly, this study was designed to determine the regulation level of PK and PEPCK by analyzing the mRNA levels and enzymatic activities in the adductor muscle. The end products such as alanine, succinate and ATP were assayed to determine the metabolic status of the muscle.

\section{MATERIAL AND METHODS}

\section{Experiment 1: Dose Effect of Sulphide on Clearance and Oxygen Consumption Rates}

\section{Biological Material}

Oysters reared in Aber Wrach (Finistère, France) were collected in May 2006 and transported to the Ifremer Shellfish Laboratory located in Argenton (Finistère, France). They were acclimated to the laboratory conditions for one week in openflow tanks before the experiments were carried out. Temperature, salinity, and oxygen were kept constant at $19^{\circ} \mathrm{C}, 35 \%$ and 7-8 $\mathrm{mg} \mathrm{O}_{2} \mathrm{~L}^{-1}$. Phytoplankton was supplied at a concentration of approximately 30,000 cell $\mathrm{mL}^{-1}$ of the unicellular algae Isochrysis galbana.

\section{Incubation in the Presence of Sulphide}

Stock solutions of hydrogen sulphide were prepared by dis-

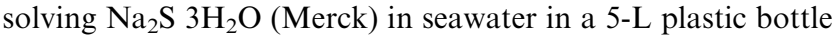
and oxidation was prevented by bubbling nitrogen through the solution. The sulphide solutions were prepared to obtained the final concentrations that were assayed in the outflow: $3,6,12$, 20 , and $40 \mu \mathrm{M}$. Sulphide was continuously injected in the flow water supplying the measurement chambers (see later) using a peristaltic pump. The sulphide concentration was checked three times a day using a sulphide test adapted for seawater (Spectroquant kit from Merck). The different sulphide levels tested were constant over the time of the measurements of clearance and oxygen consumption rates.

\section{Ecophysiological Measurement System}

The laboratory is fitted with an ecophysiological system, which allows the simultaneous monitoring of the clearance rate $\left(\mathrm{CR}, \mathrm{L} \cdot \mathrm{h}^{-1}\right)$ and oxygen consumption rate $\left(\mathrm{OC}, \mathrm{mg} \mathrm{O}_{2} \cdot \mathrm{h}^{-1}\right)$ in 8 individual open-flow chambers of $0.8 \mathrm{~L}$. Seven oysters were placed, successively, in one of the individual chambers. The eighth chamber was kept empty and used as a control. Flow rates in the individual chambers were constant and equal to $100 \mathrm{~mL} \mathrm{~min}^{-1}$ of sea water filtered at $5 \mu \mathrm{m}$. The out-flowing water of each chamber was successively analyzed for phytoplankton (fluorescence) and oxygen concentrations, which were recorded each for 5 min continuously during $20 \mathrm{~h}$.
$\mathrm{CR}$, an indicator of feeding activity, is defined as the volume of water cleared of suspended particles per unit time. In this study, CR was estimated by using fluorescence recordings. CR was calculated as follows: $(C 1-C 2) \times F R$. $C 1$ was the fluorescence level of the control chamber; $C 2$ was the fluorescence of the experimental chamber containing one oyster. FR was the flow rate. The OC rate is defined as the quantity of oxygen consumed by the animal per unit time $\left(\mathrm{mg} \mathrm{O}_{2} \cdot \mathrm{h}^{-1}\right)$. Differences in the oxygen concentration between reference and experimental chambers can be used to calculate the $\mathrm{OC}$ rate, as follows: $(O 2-O 1) \times F R$. O1 was the oxygen level of the control chamber; $O 2$ was the oxygen level of the experimental chamber containing one oyster. $\mathrm{CR}$ and $\mathrm{OC}$ rate were thus calculated, and an average was calculated for each animal. To compare $\mathrm{CR}$ and $\mathrm{OC}$ rates on the same basis, it was necessary to correct for weight differences. At the end of each experiment oysters were freeze dried for $72 \mathrm{~h}$, and their dry weight obtained. Physiological rate was then converted to a "standard" animal of $1 \mathrm{~g}$ tissue weight using the following equation: $\mathrm{Ys}=(\mathrm{Ws} / \mathrm{We})^{\mathrm{b}} \times$ $\mathrm{Ye}$, where $\mathrm{Ys}$ is the physiological rate for an animal of standard weight, $W s$ the standard weight $(1 \mathrm{~g})$, We the observed weight of the animal (g), Ye the uncorrected (measured) physiological rate, and $\mathrm{b}$ the weight exponent for the physiological rate function. The average $\mathrm{b}$ weight exponents are 0.66 and 0.75 for $\mathrm{CR}$ and $\mathrm{OC}$ respectively in bivalves (Savina \& Pouvreau 2004).

\section{Experiment 2: Effect of Chronic Exposure to Sulphide During Conditioning}

\section{Biological Material and Experimental Design}

The experiment was performed in June 2006. Oysters collected in south Brittany (La Trinité sur mer, Morbihan) were placed in 300 -L experimental tanks supplied with $80 \mathrm{~L} \mathrm{~h}^{-1}$ of $20 \mu \mathrm{m}$-filtered running seawater. The average mean weight of oysters was $6.88 \pm 0.9 \mathrm{~g}$. Eight hundred oysters were placed in each tank and were first adapted for one week to the laboratory temperature of $19^{\circ} \mathrm{C}$ and fed with an algal diet composed of Isochrysis at a daily ration close to saturation level. The medium was continuously homogenized using an immersed pump. Two different conditions were tested for 10 days: (1) 4 control tanks, where oysters were kept in air saturated seawater and fed; (2) 4 experimental tanks, where oysters were exposed to sulphide and fed. To limit the impact of oxygen on sulphides, the air-water interface was blocked with sheets of floating PVC covering $95 \%$ of surface. Mortality was checked daily in each tank. Recordings were made on day $0,2,4$, and 10 for metabolic parameters in whole oyster and gene expression measurements in adductor muscle. Eight replicates of 6 pooled whole oysters were prepared, frozen immediately, and stored in liquid nitrogen. Frozen pooled oyster were then powdered with a Dangoumeau grinder and stored in liquid nitrogen. For gene expression and enzyme activity measurements, muscle were dissected, frozen immediately, 8 replicates of 6 pooled muscle were prepared, powdered with a Dangoumeau grinder and stored in liquid nitrogen.

\section{Sulphide Exposure}

Daily, $2 \mathrm{~g}$ of $\mathrm{Na}_{2} \mathrm{~S} 3 \mathrm{H}_{2} \mathrm{O}$ (Merck) were dissolved in seawater and put directly in the $300 \mathrm{~L}$ tanks in which sulphide concentration was increased to $50 \mu \mathrm{M}$. To prolong sulphide exposure, $50 \mathrm{~L}$ of $3 \mathrm{mM}$ sulphide were prepared each day by dissolving 
$20 \mathrm{~g}$ of $\mathrm{Na}_{2} \mathrm{~S} 3 \mathrm{H}_{2} \mathrm{O}$ in sea water and stored in a plastic bottle; oxidation was prevented by bubbling nitrogen through the solution. Sulphide was continuously supplied to the tanks using a peristaltic pump. The sulphide concentration was measured three times a day using the Spectroquant kit from Merck for sulphide. The immersed pumps ensured the homogenization of sulphides in the medium. Because of the large volume of the tanks, it was difficult to maintain the sulphide concentration of the water within precise limits. Nevertheless, the procedure used ensured that the oysters were exposed to sulphide concentration above $20 \mu \mathrm{M}$ for at least $5 \mathrm{~h}$ each day.

\section{PK and PEPCK Activities}

Powdered frozen tissues were used for the enzyme assays. Using a 1:5 w/v ratio for all tissues, the aliquots were homogenized in a buffer composed of $50 \mathrm{mM}$ imidazole- $\mathrm{HCl}$ buffer (pH 7.2), $100 \mathrm{mM}$ Na3F, $5 \mathrm{mM}$ EDTA, $5 \mathrm{mM}$ EGTA, and 15 $\mathrm{mM} 2$ 2-mercaptoethanol. A few crystals of phenylmethylsulfonyl (PMSF) were added immediately prior to homogenization. The homogenates were centrifuged for $20 \mathrm{~min}$ at $20000 \mathrm{~g}$ at $5^{\circ} \mathrm{C}$. Assays were conducted at $30^{\circ} \mathrm{C}$ and initiated by mixing the $230 \mu \mathrm{L}$ reagent preparation, with the homogenate $(20 \mu \mathrm{L})$. The preparation for Pyruvate kinase (PK; EC 2.7.1.40) was as follows: $100 \mathrm{mM}$ imidazole- $\mathrm{HCl}$ buffer ( $\mathrm{pH} 7.2), 50 \mathrm{mM} \mathrm{KCl}$, $5 \mathrm{mM} \mathrm{MgCl} 2,10 \mathrm{mM}$ phosphoenol pyruvate, $2 \mathrm{mM}$ ADP, 0.15 mM NADH, $0.2 \% 2(\mathrm{v} / \mathrm{v})$ rotenone-saturated ethanol, and $1 \mathrm{U} /$ $\mathrm{mL}$ LDH. For Phosphoenolpyruvate carboxykinase (PEPCK; EC 4.1.1.32) the preparation was: $100 \mathrm{mM}$ imidazole- $\mathrm{HCl}$ buffer (pH 6.6), $30 \mathrm{mM}$ 2-mercaptoethanol, $5 \mathrm{mM}$ phosphoenolpyruvate, $50 \mathrm{mM}$ NaHCO3, $1.25 \mathrm{mM}$ IDP, $1 \mathrm{mM} \mathrm{MnCl}$, $0.15 \mathrm{mM} \mathrm{NADH}$, and $2.5 \mathrm{U} / \mathrm{mL} \mathrm{MDH}$. Blanks were run and subtracted. Changes in NAD $(\mathrm{P}) \mathrm{H}$ absorbance at $340 \mathrm{~nm}$ were monitored using a Biotek Microplate Reader.

\section{Total RNA Extraction, cDNA Synthesis and PK and PEPCK mRNA Expression}

Total RNA was isolated using Extract-all reagent (Eurobio) at a concentration of $1 \mathrm{~mL} / 50 \mathrm{mg}$ tissue. Samples were then treated with DNAse I (Sigma) (1 U/ $\mu$ g RNA) and precipitated by sodium acetate (3M, pH 5.2) treatment followed by washing with absolute ethanol. The polyadenylated RNA of samples were reverse-transcribed from $1 \mu \mathrm{g}$ of total RNA denatured for $10 \mathrm{~min}$ at $70^{\circ} \mathrm{C}$. Reactions were carried out in a total volume of $25 \mu \mathrm{L}$ with the following concentrations of the reaction components: $1 \times$ M-MLV Reverse Transcriptase buffer, $0.2 \mathrm{mM}$ dNTPs, 4 mM DTT, $0.5 \mu \mathrm{g}$ oligo(dT) primer, $25 \mathrm{U}$ ribonuclease inhibitor and $50 \mathrm{U}$ M-MLV Reverse Transcriptase. Reverse transcription (RT) was carried out for $10 \mathrm{~min}$ at $25^{\circ} \mathrm{C}, 20 \mathrm{~min}$ at $42^{\circ} \mathrm{C}$, and then $5 \mathrm{~min}$ at $94^{\circ} \mathrm{C}$.

Amplification of elongation factor I cDNA (EFI) (Fabioux et al. 2004) was performed to confirm the steady-state level of expression of a housekeeping gene, providing an internal control for PK and PEPCK gene expression (Le Moullac et al. 2007a). The specific primers were synthesized as follows: (PK) PKHui1, 5'-ACATGATTTTCGCGTCCTTC-3'; PKHui2R, 5' - TCTCTGGGGGAATCTCAATG-3' ; (PEPCK) PEPCKPEPH1, 5'-CATGGCGTCATGGTTGGA GC-3', PEPCKPEPH2R, 5'-GTCAAGCCAGTGCTGT AGG-3'. The real-time PCR assay was performed in triplicate with $5 \mu \mathrm{L}$ cDNA ( $1 / 5$ dilution) in a total volume of $15 \mu \mathrm{L}$. The concentrations of the reaction components were $0.33 \mu \mathrm{M}$ of each primer and $1 \times$ iQ SYBR Green Supermix (Biorad). This reaction was performed as follows: activation at $95^{\circ} \mathrm{C}$ for $5 \mathrm{~min}$ followed by 45 cycles of $30 \mathrm{sec}$ at $95^{\circ} \mathrm{C}, 1 \mathrm{~min}$ at $60^{\circ} \mathrm{C}$, and a melting curve program from $95^{\circ} \mathrm{C}$ to $70^{\circ} \mathrm{C}$ that decreased the temperature by $0.5^{\circ} \mathrm{C}$ every $10 \mathrm{sec}$. Each run included a positive cDNA control (one sample of the experimental mixture analyzed per amplification plate), negative controls (replicates of each total RNA sample without reverse transcriptase), and blank controls (water) for each primer pair. PCR efficiency (E) was determined by drawing standard curves from a serial dilution analysis of cDNA from samples to ensure that $\mathrm{E}$ ranged from $99 \%$ to $100 \%$ for each primer pair. The fluorescence threshold value was calculated using the Icycle iQ system software. mRNA expression levels were calculated using the $\Delta \Delta \mathrm{Ct}$ method (Livak \& Schmittgen 2001). The relative expression of a target gene (PK, PEPCK) was calculated based on the Ct deviation of this target gene versus the reference gene (EFI) and normalized to the positive control to avoid bias between the PCR. The $2^{-\Delta \Delta \mathrm{Ct}}$ was calculated as follow:

$$
\Delta \Delta \mathrm{Ct}=\Delta \mathrm{Ct}_{1}-\Delta \mathrm{Ct}_{2}
$$

where $\Delta \mathrm{Ct}_{1}=\mathrm{Ct}$ sample (target gene) $-\mathrm{Ct}$ control (target gene)

and $\Delta \mathrm{Ct}_{2}=\mathrm{Ct}$ sample (EFI gene) $-\mathrm{Ct}$ control (EFI gene).

The relative quantification value $(\mathrm{Qr})$ was then expressed as $2^{-\Delta \Delta \mathrm{Ct}}$.

\section{Electron Transport System Activity}

ETS activity was determined following the method of Owens and King (1975), where INT-tetrazolium is reduced to the optically active INT-Formazan when substituted for oxygen as the terminal electron acceptor. Reagents were freshly made and kept on ice and all assay procedures were carried out in an ice bath. Tissue powder was removed from liquid nitrogen storage, placed in ETS B solution $\left(75 \mu \mathrm{M} \mathrm{MgSO}_{4} 7 \mathrm{H}_{2} \mathrm{O}, 1.5 \mathrm{mg} \mathrm{mL}^{-1}\right.$ polyvinylpyrrolidone, and $0.2 \%$ (v:v) Triton $\mathrm{X}-100$ in $0.1 \mathrm{M}$ phosphate buffer $\mathrm{pH} 8.5$ ) and sonicated. Then samples were centrifuged for $15 \mathrm{~min}\left(4^{\circ} \mathrm{C}, 3000 \mathrm{~g}\right)$. One hundred and fifty microliters supernatant were transferred in another tube to which $400-\mu \mathrm{L}$ substrate solution $\left(1.2 \mathrm{mg} \mathrm{mL}^{-1} \mathrm{NADH}, 0.2 \mathrm{mg}\right.$ $\mathrm{mL}^{-1} \mathrm{NADPH}$ in ETS B solution) and $250-\mathrm{mL}$ INT solution ( $2 \mathrm{mg} \mathrm{mL}^{-1}$ INT-tetrazolium in double distilled water $\mathrm{pH} 8.5$ ) were added. Reactions were recorded spectrophotometrically at $490 \mathrm{~nm}$ for $20 \mathrm{~min}$ at $30^{\circ} \mathrm{C}$. The absorbance value was corrected using turbidity blank.

\section{Adenylate Energy Charge, Alanine, Succinate, and Lactate Determination}

Metabolites and nucleotides were extracted from $200 \mathrm{mg}$ of the oyster powder prepared above with $2 \mathrm{~mL}$ of trichloro-acetic acid (TCA), neutralized with $1.2 \mathrm{~mL}$ of amine freon trioctylamine/trifluoro-trichloro-ethane, v:v, 1:5). Extracted nucleotides were analyzed by high-performance liquid chromatography on a reverse phase column with a counter-ion (tributylamine). $\mathrm{AEC}$ was calculated as follows: $\mathrm{AEC}=(\mathrm{ATP}+0.5 \mathrm{ADP}) /$ (ATP + ADP + AMP) (Moal et al. 1991).

Alanine was measured enzymatically according to standard procedures as described by Williamson (1974). Succinate was quantified with the succinate determination kit of R-Biopharm Inc. (Marshall, MI, USA). 


\section{Statistics}

A one-way ANOVA followed by a Fisher test was used to determine the effect of sulphide concentration on the clearance and respiration rates of oysters. Concerning the impact of the chronic sulphide exposure for 10 days, a one-way ANOVA followed by Fisher test was used to determine if individual time point means differed from day 0 means within each oxygen level group. T-tests were used to determine the differences between means of control and sulphide group at each time point.

Kinetic properties of PK enzyme were defined as Greenway and Storey (2000). The substrate affinity constant $\left(S_{0.5}\right)$ is defined as the concentration of substrate at which the enzyme the enzyme reaction proceeds at $50 \%$ of its maximal velocity. $\mathrm{S}_{0.5}$ is defined by fitting data from the double reciprocal plots (Lineweaver-Burk plot) of rate versus substrate (PEP) concentration. $\mathrm{I}_{50}$ is defined as the concentration of inhibitor (alanine) required to reduce enzymes activity to half its value in the absence of inhibitor. $\mathrm{I}_{50}$ values were obtained from the Dixon plots of rate versus inhibitor concentration. Statistical analyses were performed using Statview (SAS).

\section{RESULTS}

\section{Experiment 1: Dose Effect of Sulphide on Clearance Rate and Oxygen Consumption}

Filtration rate was significantly reduced at sulphide concentrations between $6 \mu \mathrm{M}$ and $20 \mu \mathrm{M}$ then stopped at concentrations over $40 \mu \mathrm{M}$ (Fig. 1a). The adaptation of oxygen uptake of oysters to sulphide exposure revealed three steps using the post hoc test rank of Fisher (1) to low dose tested, at 3 and $5 \mu \mathrm{M}$ sulphide, the oysters increased their oxygen uptake signifi-
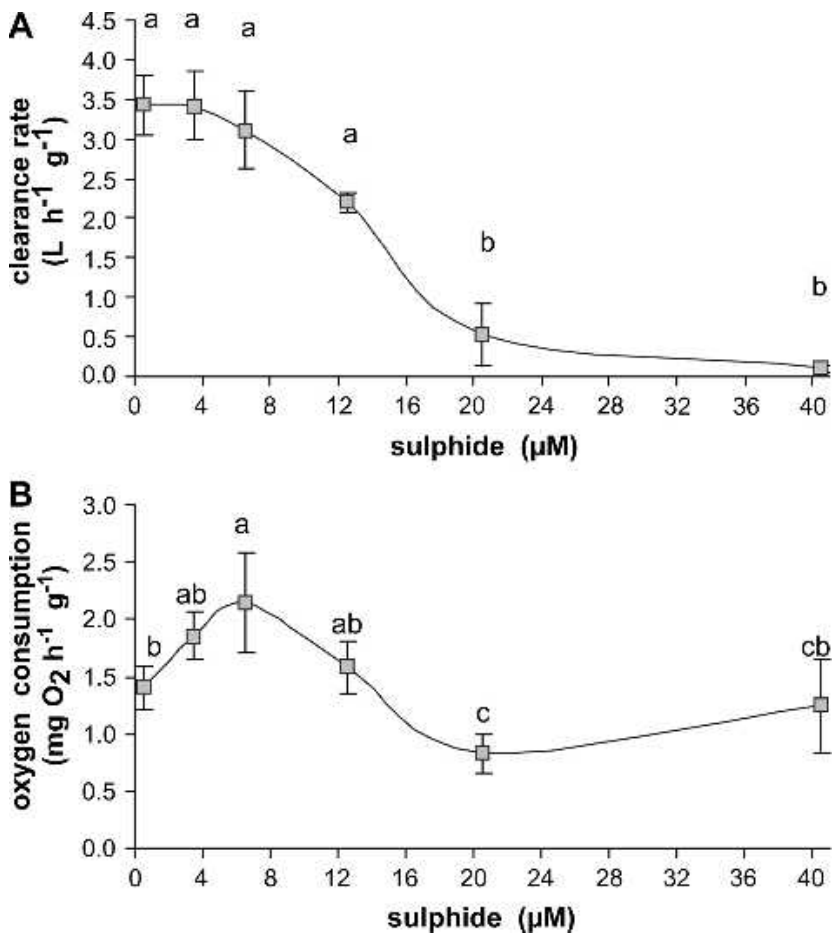

Figure 1. The effects of sulphide concentration on clearance rate (a), and oxygen consumption (b) of the oyster $C$. gigas. Results are means $\pm \mathrm{SE}$, $n=7$. cantly, (2) at 12 and $20 \mu \mathrm{M}$, the oxygen consumption decreased significantly, (3) then between 20 and $40 \mu \mathrm{M}$ oxygen uptake remained stable (Fig. 1b).

\section{Experiment 2: Effect of Chronic Exposure to Sulphides During Conditioning}

\section{Mortality}

The mortality of oysters exposed to sulphide was significantly higher $(P<5 \%)$ than among control oysters. After 10 days of exposure to sulphide, the mortality of oysters was $53 \pm$ $16.4 \%$ whereas the mortality of control oysters was $35 \pm 2.5 \%$. The mortality of sulphide-exposed oysters occurred precisely between days 4 and 6 (Fig. 2).

\section{PK and PEPCK Enzyme Activity in the Whole Oysters}

Chronic exposure to sulphide for 10 days induced a significant decreased of PK activity in whole oysters compared with control oysters (Fig. 3a). As early as day 2, PK activity in sulphide exposed oysters decreased significantly and values were reduced by half at day 2,4 , and 10 . PK activity in control oysters was significantly lower at day 2, 4, and 10 than at day 0 . PEPCK differed significantly at the $5 \%$ level (T-test) from that of control oysters only after 10 days of sulphide exposure (Fig. 3b).

\section{Metabolite Content and AEC in the Whole Oysters}

Chronic exposure to sulphide induced a significant increase of the alanine content in sulphide exposed whole oysters at day $4(P<5 \%)$. Succinate content did not change with sulphide exposure (Table 1). A comparison of AEC means showed significant differences at day 2 and 4 between control and sulphide exposed oysters $(P<5 \%)$ (Table 1$)$.

\section{ETS Activity in the Whole Oysters}

The activity of the electron transport system decreased significantly in oyster exposed to sulphide for 10 days. The comparison of ETS means showed a significant difference at day 2 and 4 between control and sulphide exposed oysters $(P<$ $5 \%)$. A significant decrease was recorded between the ETS mean at day 0 and ETS means at day 2 and $4(P<5 \%)$ (Fig. 4$)$.

\section{Regulation Level of the PEP Branchpoint in the Adductor Muscle}

PK Gene Expression and Enzyme Activity

Chronic exposure to sulphide for 10 days did not induced a significant effect on PK mRNA values despite a slight increase

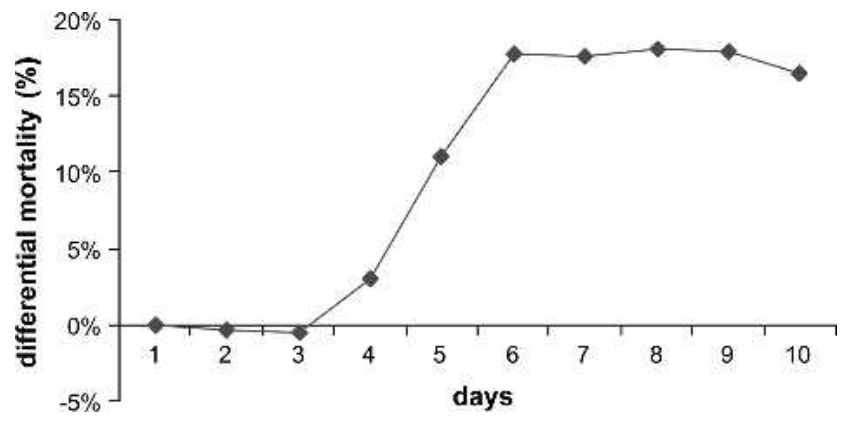

Figure 2. Differential mortality between sulphide and control treatments. 

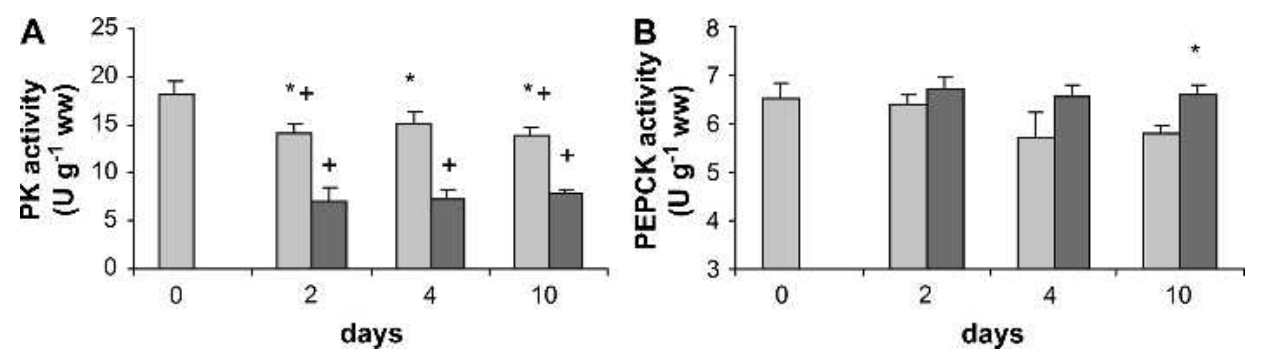

Figure 3. The effects of sulphide on (a) PK and (b) PEPCK enzyme activity in whole oyster. Control (grey) and sulphide (dark). Results are means \pm $\mathrm{SE}, n=8$. *, significant difference $(P<0.05)$ relative to day 0 within each group. + , significant difference $(P<0.05)$ between control and sulphide at each sampling day.

in muscle of oyster exposed to sulphide (Fig. 5a). At enzyme level, sulphide exposure induced a significant decreased of PK enzyme activity in the adductor muscle (Fig. 5b). The Student $t$-test showed significant differences $(P<5 \%)$ between control and sulphide at day 2,4 , and 10 .

The elongation factor $I$, used as an internal control for gene expression, did not revealed significant differences at the $5 \%$ level between treated and non-treated oysters (Student $t$-test).

\section{PEPCK Gene Expression and Enzyme Activity}

PEPCK gene expression was significantly upregulated in the adductor muscle of oyster exposed to sulphide. The PEPCK mRNA values in the adductor muscle increased significantly (Fig. 5c). The student $t$-test showed significant temporal changes leading to the increase of PEPCK mRNA value from day 0 to day $10(P<5 \%)$ (Fig. 5c). The student $t$-test showed also a significant increase of PEPCK $m$ RNA value $(P<5 \%)$ in sulphide treatment at day 2 (Fig. 5c). At enzyme level, the exposure to sulphide did not change significantly the level of the PEPCK activity.

\section{Metabolite and Energy Production in the Adductor Muscle}

The alanine accumulated significantly in the muscle. The student $t$-test revealed that the alanine accumulation was significantly higher $(P<5 \%)$ at day 2 and 4 (Table 2$)$. In the same way, succinate accumulated significantly in the muscle. The student $t$-test revealed that the succinate accumulated significantly $(P<5 \%)$ at day 2 and 4 (Table 2$)$. ATP production decreased significantly in adductor muscle of oyster exposed to sulphide. The student $t$-test revealed that the ATP content remained significantly lower $(P<5 \%)$ from day 2 to day 10 (Table 2).
Kinetic properties of $P K$

Sulphide exposure led to significant change in the kinetic properties of PK enzyme activity in muscle. The PEP affinity constant $\left(\mathrm{S}_{0,5}\right)$ was significantly $(P<5 \%)$ reduced by 1.6 fold (Table 3). PK enzyme activity from muscle of oyster exposed to sulphide also showed much greater inhibition by L-alanine, with the $I_{50}$ value reduced to only $33 \%$ of the corresponding control value.

\section{DISCUSSION}

\section{Sulphide Affects Ecophysiological Behavior}

Our results showed that oysters are able to react to sulphide exposures at several biological scales. Clearance rate and oxygen consumption were progressively affected by exposure to sulphide. Changes in oxygen consumption rate were recorded over the range of sulphide concentration tested for $20 \mathrm{~h}$, but feeding stopped at concentrations above $20 \mu \mathrm{M}$ showing that oxygen consumption was driven independently of the mechanism of microalgae retention. Sulphide acted on $C$. gigas like hypoxia to cut hunger (Le Moullac et al. 2007a, 2007b).

The pattern of oxygen uptake according to the increase of sulphide concentration was first an increase up to a concentration of $6 \mu \mathrm{M}$. A negative energy budget could be fear at the low doses of sulphide when the OC was accelerated, whereas feeding remained constant. Then the oxygen uptake decreased slightly to reach a mean oxygen uptake of approximately $1 \mathrm{mg} \mathrm{O}_{2} \mathrm{~h}^{-1} \mathrm{~g}^{-1}$ at sulphide concentration between 12 and $40 \mu \mathrm{M}$. This may be caused by oxygen being used to oxidize sulphide entering the tissues rather than to an actual increase of the metabolic rate of the tissues (Johns et al. 1997, Hauschild \& Grieshaber 1997). An increase in the rate of oxygen consumption during exposure to

TABLE 1.

Alanine, succinate content and AEC in control and oyster exposed to sulphide during 10 days $(n=8$, means \pm SE).

\begin{tabular}{|c|c|c|c|c|c|c|}
\hline \multirow[b]{2}{*}{ Days } & \multicolumn{2}{|c|}{ Alanine $\left(\mu \mathrm{M} \mathrm{g}^{-1} \mathrm{ww}\right)$} & \multicolumn{2}{|c|}{ Succinate $\left(\mu \mathbf{M ~ g}^{-1} \mathrm{ww}\right)$} & \multicolumn{2}{|c|}{ AEC } \\
\hline & Control & Sulphide Exposed & Control & Sulphide Exposed & Control & Sulphide Exposed \\
\hline 0 & $17.23 \pm 1.69$ & & $1.98 \pm 0.31$ & & $0.811 \pm 0.006$ & \\
\hline 2 & $16.30 \pm 1.47$ & $18.12 \pm 1.52$ & $2.23 \pm 0.14$ & $2.46 \pm 0.20$ & $0.803 \pm 0.005^{*}$ & $0.759 \pm 0.017^{+}$ \\
\hline 4 & $14.80 \pm 1.19$ & $24.52 \pm 1.68^{+*}$ & $1.18 \pm 0.16$ & $1.73 \pm 0.26$ & $0.817 \pm 0.006^{*}$ & $0.764 \pm 0.015^{+}$ \\
\hline 10 & $12.79 \pm 1.37$ & $13.78 \pm 0.66$ & $1.65 \pm 0.28$ & $1.32 \pm 0.22$ & $0.807 \pm 0.004$ & $0.792 \pm 0.008$ \\
\hline
\end{tabular}

+ , significant difference $(P<0.05)$ relative to day 0 within each group.

*, significant difference $(P<0.05)$ between control and sulphide at each sampling day. 


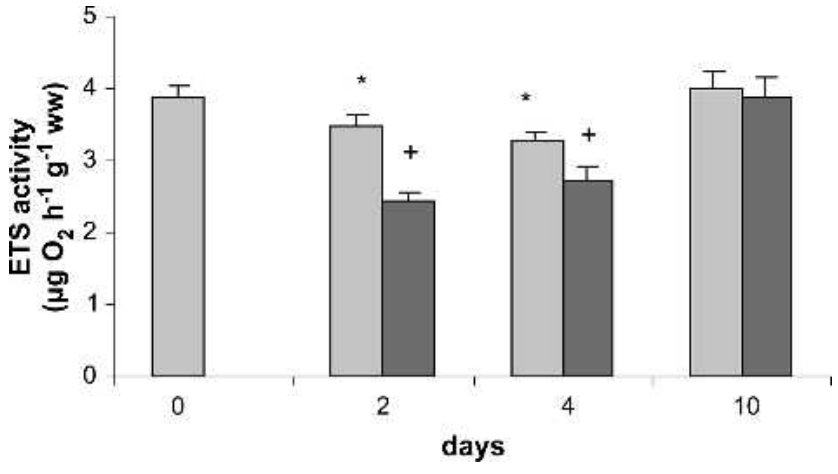

Figure 4. The effects of sulphide on ETS activity in whole oyster. Control (grey) and sulphide (dark). Results are means $\pm \mathrm{SE}, n=8$. *, significant difference $(P<0.05)$ relative to day 0 within each group. + , significant difference $(P<0.05)$ between control and sulphide at each sampling day.

low concentrations of sulphide has been already recorded in several marine invertebrates (Eaton \& Arp 1993, Johns et al. 1997) whereas in others the oxygen consumption rate remained constant (Encomio 1998, Christensen \& Colacino 2000).

\section{Oyster Exposed to Sulphide Exhibited Partially an Anaerobic Metabolism}

At the cellular level, our results showed the whole organism is partially involved towards an anaerobic metabolism of energy production. Sulphide exposure of oysters resulted in higher mortality, reduced the glycolytic flux by inhibiting the PK activity. Alanine content increased only on day 4 and we failed to detect any accumulation of succinate in sulphidic whole oysters. ETS activity decreased leading to a lower AEC. At day 10, a kind of recovery took place in the respiratory chain: the ETS activity and AEC of oysters exposed to sulphide increased to the level of the control oysters.

During extended sulphide exposure an aerobic-based metabolism cannot be sustained. Indeed, worms Arenicola marina
(Hauschild \& Grieshaber 1997), Urechis caupo (Encomio 1998), clams Mulinia lateralis, and Donax serra (Shumway et al. 1983, Laudien et al. 2002), and the crustacean Cyprideis torosa (Jahn et al. 1996) exposed to sulphide exhibited an anaerobic metabolism, showing a decrease of total glycogen phosphorylase enzyme activity (Oeschger \& Storey 1993), and an increase of alanine (Oeschger \& Storey 1993, Encomio 1998, Laudien et al. 2002) and succinate production (Oeschger \& Pedersen 1994, Encomio 1998, Laudien et al. 2002). The polychaete worm $A$. marina kept under normoxic conditions became anaerobic in the presence of $25 \mu \mathrm{M}$ sulphide (Hauschild \& Grieshaber, 1997) that was close to the $20 \mu \mathrm{M}$ threshold where clearance rate decreased in C. gigas in the first experiment of this study.

\section{Muscle of Oyster Exposed to Sulphide Exhibited a Wholly Anaerobic Metabolism}

In muscle of oyster exposed to sulphide, the anaerobic pathway of energy production was clearly marked: inhibition of PK enzyme activity, increase of alanine and succinate followed by a decrease of ATP content during the 10 days sulphide exposure. However, the PEPCK enzyme activity was not stimulated. Sulphide did not affect the transcriptional level of PK; PK was only regulated at enzyme level. The nutritional restriction of oyster exposed to sulphide stimulated alanine production in muscle like fasting in vertebrate and invertebrate (Müller et al. 1971, Okama \& Abe, 1998). Alanine is linked to the mechanism of PK inhibition, consisting in covalent modification via phosphorylation mechanism that greatly increases PK enzyme inhibition by alanine (Plaxton \& Storey 1984, Storey 1993). Conversely, PEPCK was regulated only at transcriptional level. Nutritional restriction acts on PEPCK by inducing gene expression (Lemaigre \& Rousseau 1994), because PEPCK gene expression is negatively linked to glucose (Meyer et al. 1991). But, the absence of change in PEPCK activity could be attributed to a loss of efficiency in the ARNm translation caused by sulphide.
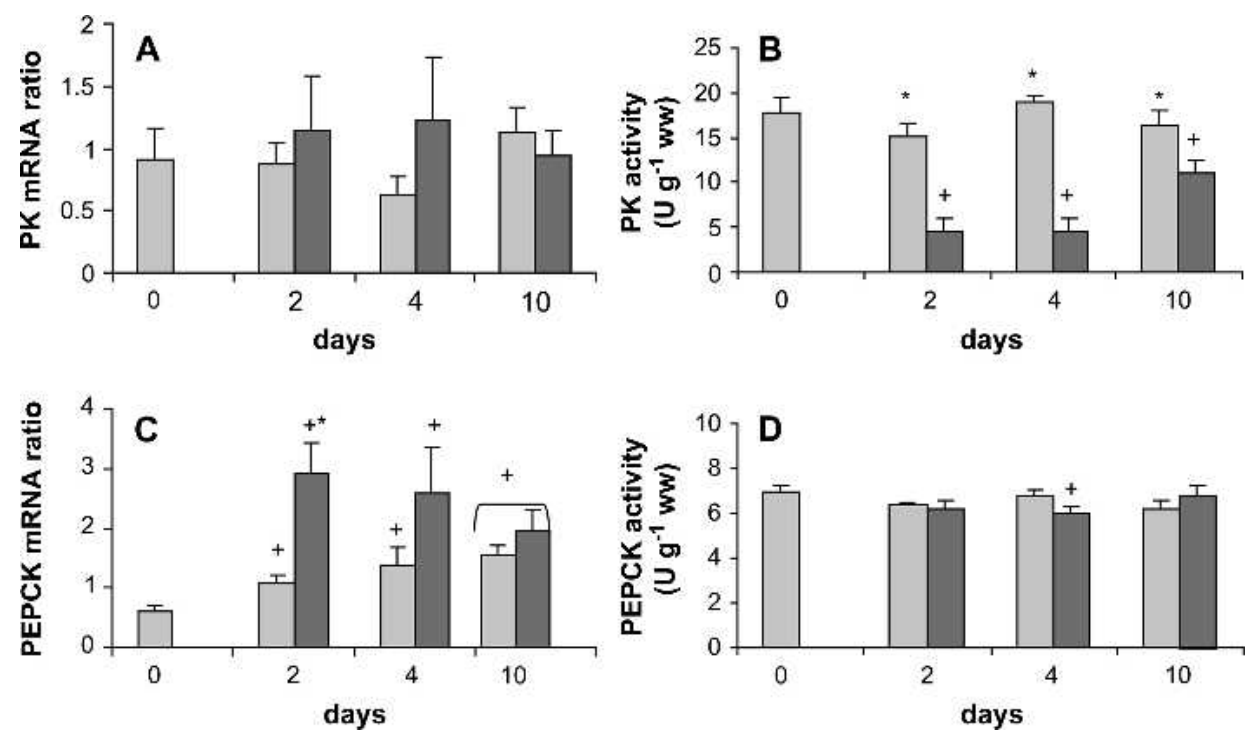

Figure 5. Variation of PK and PEPCK mRNA ratio (relative to Elongation factor I) and enzyme activity in muscle in normoxia (grey) and sulphide exposed (dark). PK mRNA ratio (A), PK activity (B), PEPCK mRNA (C) ratio and PEPCK activity (D). Results are means \pm SE, $n=8$. *, significant difference $(P<0.05)$ relative to day 0 within each group. + , significant difference $(P<0.05)$ between control and sulphide at each sampling day. 
TABLE 2.

Alanine, succinate and ATP content in the adductor muscle of control and oyster exposed to sulphide during 10 days $(n=8$, means $\pm \mathrm{SE})$.

\begin{tabular}{|c|c|c|c|c|c|c|}
\hline \multirow[b]{2}{*}{ Days } & \multicolumn{2}{|c|}{ Alanine $\left(\mu M g^{-1} w w\right)$} & \multicolumn{2}{|c|}{ Succinate $\left(\mu M g^{-1} w w\right)$} & \multicolumn{2}{|c|}{$\operatorname{ATP}\left(\mu M g^{-1} w w\right)$} \\
\hline & Control & Sulphide Exposed & Control & Sulphide Exposed & Control & Sulphide Exposed \\
\hline 0 & $13.55 \pm 1.21$ & & $1.68 \pm 0.36$ & & $3.25 \pm 0.34$ & \\
\hline 2 & $11.60 \pm 0.82$ & $16.22 \pm 1.02 *$ & $1.17 \pm 0.21$ & $2.63 \pm 0.34^{*}$ & $2.69 \pm 0.15$ & $1.85 \pm 0.17^{+*}$ \\
\hline 4 & $10.63 \pm 0.52^{+}$ & $15.68 \pm 1.52^{*}$ & $0.99 \pm 0.20$ & $1.85 \pm 0.20^{*}$ & $2.44 \pm 0.10^{+}$ & $1.80 \pm 0.14^{+*}$ \\
\hline 10 & $10.81 \pm 0.68$ & $10.82 \pm 0.70$ & $0.89 \pm 0.18$ & $1.22 \pm 0.22$ & $2.76 \pm 0.09$ & $2.45 \pm 0.09^{+*}$ \\
\hline
\end{tabular}

+ , significant difference $(P<0.05)$ relative to day 0 within each group.

*, significant difference $(P<0.05)$ between control and sulphide at each sampling day.

\section{Tolerance and Adaptation of Oyster to Sulphides}

Results lead to the conclusion that the physiology of the oyster can be severely affected by sulphide exposure. Sulphide exposure increases the susceptibility of organisms to other environmental stressors and the mortality rate of marine invertebrates increases when exposed to sulphide (Laudien et al. 2002, Robohm et al. 2005). This fact was confirmed in our experiment by the high mortality rates demonstrating the toxicity of sulphide for oyster. Organisms inhabiting sulphide contaminated environments have developed strategies to cope with sulphide. The long-term exposure of $C$. gigas to sulphide had as consequence a type of recovery where the activity of the respiratory chain became again normal that could favor the setting of a sulphide detoxification mechanism. In sulphidic areas, survival of Arctica islandica is because of the combination of several mechanisms where at cellular level glutathione oxidizes sulphide, and where in blood L-cysteine reactivates enzymes inhibited by sulphide (Butterworth et al. 2004). Otherwise, the tolerance of sulphide would also be caused by a better protection of cytochrome c oxidase by slower sulphide diffusion into the tissues (Jahn \& Theede 1997).

\section{Sulphide, an Environmental Stressor Partially at the Origin of} Summer Mortalities?

Our study establishes several factors that are important in helping us to obtain a better understanding of mortality events in the field. The significant mortality of control oysters must be judged within the context of summer mortalities (Goulletquer et al. 1998, Samain et al. 2007). The thermal and physiological

TABLE 3.

Kinetic properties of PK from adductor muscle of Crassostrea gigas control and exposed to sulphide.

\begin{tabular}{lcc}
\hline \hline & \multicolumn{1}{c}{ Control } & Sulphide Exposed \\
\hline $\mathrm{S}_{0.5}$ PEP mM & $0.33 \pm 0.08$ & $0.55 \pm 0.05^{\mathrm{a}}$ \\
$\mathrm{I}_{50}$ L-alanine $\mathrm{mM}$ & $11.33 \pm 2.12$ & $3.78 \pm 0.81^{\mathrm{a}}$ \\
\hline
\end{tabular}

The results are given as means $\pm \mathrm{SE}(n=15-18)$.

All parameters were determined at $2 \mathrm{mM}$ ADP. $\mathrm{I}_{50}$ L-alanine was determined at $5 \mathrm{mM}$ PEP.

${ }^{a}$ Significantly different from control. conditions were able to trigger mortality: the temperature was $20^{\circ} \mathrm{C}$ and the oysters were ripe (Soletchnik et al. 1999). In this study, we showed that sulphide may cause mortalities among cultivated oysters and could result from sulphide diffusing from the sediment into the water column. Indeed, keeping oysters in close proximity to the sediment decreases their survival and their growth rate, reduces the storage ability of energy compounds such as lipids and glycogen (Soletchnik et al. 1999, 2006), and alters the defense system (Gagnaire et al. 2006). Our study showed that sulphide exposure resulted in oyster adopting an anaerobic metabolism of energy production, whereas they needed oxygen for detoxification of sulphide compounds.

To conclude, this study has shown the effects of differing concentrations of sulphide on oysters. Firstly, the oxygen uptake was maintained, whereas filtration stopped, probably indicating that oxygen was used by the organism to detoxify sulphide by oxidation to thiosulphate. This assumption seems correct regarding the metabolic pathways. Indeed, the oysters exposed to the sulphide were anaerobic as shown by the inhibition of PK and the stimulation of PEPCK. PK and PEPCK were differentially regulated, PK was regulated at the protein level whereas PEPCK at gene level. The mechanism of PEPCK translation of mRNA into an active protein should be elucidated. At the mitochondrial level, there was a two-stage response. Firstly, the rapid reduction in the ETS activity implied a decrease in ATP production. Secondly after 10 days, a type of recovery took place, which could result in a better detoxification capacity of the organism, whereas the anaerobic state was able to maintain a supply of energy. Further studies should be carried out to detect and quantify the metabolic end products of sulphide detoxification. These compounds are useful markers of sulphide exposure. The mechanisms controlling sulphide tolerance to sulphide in this species and those which allow the gills to continue to take up oxygen even though feeding stops should be elucidated.

\section{ACKNOWLEDGMENT}

This work was supported by the Morest national project funded by Ifremer, the Régions of Basse Normandie, Bretagne, Pays de Loire and Poitou-Charentes and the Conseil Général du Calvados. The authors also thank Michel Mathieu, director of the UMR 100, Physiologie et Ecophysiologie des Mollusques Marins and Alan C. Taylor for improving the English in this paper. 


\section{LITERATURE CITED}

Butterworth, K. G., M. K. Grieshaber \& A. C. Taylor. 2004. Sulphide detoxification in the bivalve, Arctica islandica (L.) from two different habitats. Ophelia 58:101-113.

Chapelle, A., P. Lazure \& P. Souchu. 2001. Modélisation numérique des crises anoxiques (malaïgues) dans la lagune de Thau (France). Oceanologica Acta 24:87-97.

Christensen, A. B. \& J. M. Colacino. 2000. Respiration in the burrowing brittlestar, Hemipholis elongate Say (Echinodermata, Ophiuroidea): a study of the effects of environmental variables on oxygen uptake. Comp. Biochem. Physiol. 127:201-213.

Dégremont, L., E. Bédier, P. Soletchnik, M. Ropert, A. Huvet, J. Moal, J. F. Samain \& P. Boudry. 2005. Relative importance of family, site, and field placement timing on survival, growth, and yield of hatchery-produced Pacific oyster spat (Crassostrea gigas). Aquaculture 249:213-229.

De Zwaan, A., P. Cortesi, G. van den Thillart, J. Roos \& K. B. Storey. 1991. Differential sensitivies to hypoxia by two anoxia-tolerant marine molluscs: a biochemical analysis. Mar. Biol. 111:343 351.

Diaz, R. J. \& R. Rosenberg. 1995. Marine benthic hypoxia: a review of its ecological effects and the behavioural responses of benthic macrofauna. Ocean. Mar. Biol.: an Annual Review 33:245-303.

Eaton, R. A. \& A. J. Arp. 1993. Aerobic respiration during sulphide exposure in the marine echiuran worm Urechis caupo. Physiol. Zool. 66:1-19.

Encomio, V. G. 1998. Respiratory and metabolic response to sulfide and hypoxia in the marine echiuran worm, Urechis caupo. San Francisco State University, Thesis, $74 \mathrm{pp}$.

Fabioux, C., A. Huvet, C. Lelong, R. Robert, S. Pouvreau, J. Y. Daniel, C. Mingant \& M. Le Pennec. 2005. Oyster vasa-like gene as a marker of the germline cell development in Crassostrea gigas. Biochem. Biophys. Res. Commun. 320:592-598.

Fanslow, D. L., T. F. Nalepa \& T. H. Johengen. 2001. Seasonal changes in the respiratory electron transport system (ETS) and respiration of the zebra mussel, Dreissena polymorpha in Saginaw Bay, Lake Huron. Hydrobiologia 448:61-70.

Gagnaire, B., P. Soletchnik, P. Madec, P. Geairon, O. Le Moine \& T. Renault. 2006. Diploid and triploid Pacific oysters, Crassostrea gigas (Thunberg), reared at two heights above sediment in Marennes-Oléron Basin, France: Difference in mortality, sexual maturation and hemocyte parameters. Aquaculture 254:606-616.

Goulletquer, P., P. Soletchnik, O. Le Moine, D. Razet, P. Geairon, N. Faury \& S. Taillade. 1998. Summer mortality of the Pacific cupped oyster Crassostrea gigas in the Bay of Marennes-Oléron (France). Cons. Int. Explor. Mer, CM 1998/CC 14, 20 p

Greenway, S. C. \& K. B. Storey. 1999. The effect of prolonged anoxia on enzyme activities in oysters (Crassostrea virginica) at different seasons. J. Exp. Mar. Biol. Ecol. 242:259-272.

Greenway, S. C. \& K. B. Storey. 2000. Seasonal change and prolonged anoxia affect the kinetic properties of phosphofructokinase and pyruvate kinase in oysters. J. Comp. Physiol. 170B:285-293.

Hauschild, K. \& M. K. Grieshaber. 1997. Oxygen consumption and sulfide detoxification in the lugworm Arenicola marina (L.) at different ambient oxygen partial pressures and sulfides concentrations. J. Comp. Physiol. 167B:378-388.

Hicks, D. W. \& R. F. McMahon. 2002. Respiratory responses to temperature and hypoxia in the nonindigenous Brown Mussel, Perna perna (Bivalvia: Mytilidae), from the Gulf of Mexico. $J$. Exp. Mar. Biol. Ecol. 277:61-78.

Jahn, A., I. Gamenick \& H. Theede. 1996. Physiological adaptations of Cyprideis torosa (Crustacea, Ostracoda) to hydrogen sulphide. Mar. Ecol. Prog. Ser. 142:215-223.

Jahn, A. \& H. Theede. 1997. Different degrees of tolerance to hydrogen sulfide in populations of Macoma balthica (Bivalvia, Telinidae). Mar. Ecol. Prog. Ser. 154:185-196.
Johns, A. R., A. C. Taylor, R. J. A. Atkinson \& M. K. Grieshaber. 1997. Sulphide metabolism in Thalassinidean Crustacea. J. Mar. Biol. Ass. U.K. 77:127-144.

Kennett, D. \& P. E. Hargraves. 1985. Benthic diatoms and sulfide fluctuations: upper basin of Pettaquamscutt River, Rhode Island. Est. Coast. Shelf. Science 21:577-586.

Laudien, J., D. Schiedek, T. Brey, H. O. Portner \& W. E. Arntz. 2002. Survivor of juvenile clams Donax serra (Bivalvia, Donacidae) exposed to severe hypoxia and hydrogen sulphide. J. Exp. Mar. Biol. Ecol. 271:9-23.

Lemaigre, F. P. \& G. G. Rousseau. 1994. Transcriptional control of genes that regulate glycolysis and gluconeogenesis in adult liver. Biochem. J. 303:1-14.

Le Moullac, G., H. Bacca, A. Huvet, J. Moal, S. Pouvreau \& A. Van Wormhoudt. 2007a. Transcriptional regulation of pyruvate kinase and phosphoenolpyruvate carboxykinase in the adductor muscle of the oyster Crassostrea gigas during prolonged hypoxia. J. Exp. Zool. 307A:371-382.

Le Moullac, G., I. Quéau, P. Le Souchu, S. Pouvreau, J. Moal, J. R. Le Coz \& J. F. Samain. 2007b. Metabolic adjustments in the oyster Crassostrea gigas according to oxygen level and temperature. Mar. Biol. Res. (in press).

Livak, K. J. \& T. D. Schmittgen. 2001. Analysis of relative gene expression data using real-time quantitative PCR and the $2(-\Delta \Delta \mathrm{C}(\mathrm{T}))$ method. Methods 25:402-408

Madon, S. P., D. W. Schneider \& J. A. Stoeckel. 1998. In situ estimation of zebra mussel metabolic rates using the electron transport system (ETS) assay. J. Shellfish Res. 17:195-203.

Meyer, S., W. Höppner \& H. J. Seitz. 1991. Transcriptional and posttranscriptional effects of glucose on liver phosphoenolpyruvatecarboxykinase gene expression. Eur. J. Biochem. 202:985-991.

Moal, J., J. R. Le Coz, J. F. Samain \& J. Y. Daniel. 1991. Adenylate energy charge: a possible trophic index for management of oyster intensive aquaculture. Comp. Biochem. Physiol. 100C:201-205.

Müller, W. A., G. R. Faloona \& R. H. Unger. 1971. The effect of alanine on glucagon secretion. J. Clin. Invest. 50:2215-2218.

Oeschger, R. \& K. B. Storey. 1993. Impact of anoxia and hydrogen sulphide on the metabolism of Arctica islandica L. (Bivalvia). J. Exp. Mar. Biol. Ecol. 170:213-226.

Oeschger, R. \& T. F. Pedersen. 1994. Influence of anoxia and hydrogen sulphide on the energy metabolism of Scrobicularia plana (da Costa) (Bivalvia). J. Exp. Mar. Biol. Ecol. 184:255-268.

Okama, E. \& H. Abe. 1998. Effects of starvation and D- or L- alanine administration on the free D- and L-alanine levels in the muscle and hepatopancreas of the crayfish, Procambarus clarkii. Comp. Biochem. Physiol. 120A:681-686.

Owens, T. G. \& F. D. King. 1975. The measurement of respiratory electron transport system activity in marine zooplankton. Mar. Biol. 30:27-36.

Plaxton, W. C. \& K. B. Storey. 1984. Purification and properties of aerobic and anoxic forms of pyruvate kinase from red muscle organ of the channeled whelk, Busycotypus canaliculatum. Eur. J. Biochem. 143:257-265.

Robohm, R. A., A. F. J. Draxler, D. Wieczorek, D. Kapareiko \& S. Pitchford. 2005. Effects of environmental stessors on disease susceptibility in American lobsters: a controlled laboratory study. J. Shellfish Res. 24:773-779.

Roden, E. E. \& J. H. Tuttle. 1992. Sulfide release from estuarine sediments underlying anoxic bottom water. Limnol. Oceanogr. 37:725-738.

Samain, J. F., L. Dégremont, P. Soletchnik, J. Haure, E. Bédier, M. Ropert, J. Moal, A. Huvet, H. Bacca, A. Van Wormhoudt, M. Delaporte, K. Costil, S. Pouvreau, C. Lambert, V. Boulo, P. Soudant, J. L. Nicolas, F. Le Roux, T. Renault, B. Gagnaire, F. Geret, I. Boutet, T. Burgeot \& P. Boudry. 2007. Genetically based resistance to summer mortality in the Pacific oyster 
(Crassostrea gigas) and its relationship with physiological, immunological characteristics and infection process. Aquaculture 268:227-243.

Savina, M. \& S. Pouvreau. 2004. A comparative ecophysiological study of two infaunal filter-feeding bivalves: Paphia rhomboids and Glycymeris glycymeris. Aquaculture 239:289-306.

Simpfendörfer, R. W., M. V. Vial \& A. Monjsalve. 1997. The adductor muscle pyruvate kinase from the intertidal bivalve Mytilus chilensis (Hupe): evidence of the presence of phosphorylated form of the enzyme during the entire tidal cycle. J. Exp. Mar. Biol. Ecol. 213:169179.

Shick, J. M., E. Gnaiger, J. Widdows, B. L. Bayne \& A. de Zwann. 1986. Activity and metabolism in the mussel Mytilus edulis L. during intertidal hypoxia and aerobic recovery. Physiol. Zool. 59:627642.

Shumway, S. E., T. M. Scott \& J. M. Shick. 1983. The effects of anoxia and hydrogen sulphide on survival, activity and metabolic rate in the coot clam, Mulinia lateralis (Say). J. Exp. Mar. Biol. Ecol. 71:135146.
Sobral, P. \& J. Widdows. 1997. Influence of hypoxia and anoxia on the physiological responses of the clam Ruditapes decussatus from southern Portugal. Mar. Biol. 127:455-461.

Soletchnik, P., O. Le Moine, N. Faury, D. Razet, P. Geairon \& P. Goulletquer. 1999. Summer mortality of the oyster in the Bay Marennes-Oléron: Spatial variability of environment and biology using a geographical information system (GIS). Aquat. Living Resour. 12:131-143.

Soletchnik, P., N. Faury \& P. Goulletquer. 2006. Seasonal changes in carbohydrate metabolism and its relationship with summer mortality of Pacific oyster Crassostrea gigas (Thunberg) in MarennesOléron bay (France). Aquaculture 252:328-338.

Storey, K. B. 1993. Molecular mechanism of metabolic arrest in molluscs. In: P. W. Hochachka, P. L. Lutz, T. Sick, M. Rosenthal, G. van den Thillart, editors. Surviving hypoxia: mechanisms of control and adaptation. Boca Raton: CRC Press. pp. 253-269.

Williamson, D. H. 1974. Determination with alanine dehydrogenase. In: H. U. Bergmeyer, editor. Methods of enzymatic analysis. Vol. 2. New York: Academic Press. pp. 1679-1682. 